\title{
Effect of artificial light on marine invertebrate and fish abundance in an area of salmon farming
}

\author{
A. McConnell ${ }^{1, *}$, R. Routledge ${ }^{2}$, B. M. Connors ${ }^{3}$ \\ ${ }^{1}$ Department of Biology, ${ }^{2}$ Department of Statistics and Actuarial Sciences, and ${ }^{3}$ Evolutionary and Behavioural Ecology \\ Research Group, Department of Biological Sciences; Simon Fraser University, 8888 University Drive, Burnaby, \\ British Columbia V5A 1S6, Canada
}

\begin{abstract}
Artificial light can change the behaviour of aquatic organisms, although the direction of response can be species and life-stage specific. Open net-pen salmon farms in British Columbia, Canada, routinely illuminate their net-pens during the winter and spring, with unknown consequences on the abundance and distribution of marine fish and invertebrates. Paired lit and control samples consisting of plankton hauls and purse seines were made around a $400 \mathrm{~W}$ underwater light such as those used on salmon farms. On lit nights, invertebrates were marginally more abundant, while fish larvae and juvenile and adult fish were significantly more abundant. In particular, the invertebrate taxa Gastropoda and Bivalvia were significantly more abundant on lit nights, as were the fish species Pacific herring Clupea pallasi, sand lance Ammodytes hexapterus, threespine stickleback Gasterosteus aculeatus, soft sculpin Psychrolutes sigalutes, and great sculpin larvae Myoxocephalus polyacanthocephalus. These results suggest that lights commonly used in open net-pen aquaculture may increase the abundance of some fish species around pens, thereby increasing the probability that farmed fish and wild species directly and indirectly interact in coastal marine environments.
\end{abstract}

KEY WORDS: Aquaculture $\cdot$ Phototaxis · Aggregation $\cdot$ Zooplankton $\cdot$ Chum salmon - Resale or republication not permitted without written consent of the publisher

\section{INTRODUCTION}

Many marine species alter their behaviour in the presence of artificial light. These responses include changes in individual behaviour, schooling behaviour, spatial distribution, migration, reproduction, and population dynamics (Longcore \& Rich 2004, Nightingale et al. 2006). The attraction to light of various organisms has been noted for decades: zooplankton and fish larvae are routinely collected in light-traps (Sheard 1941, Hale 1953, Jones 1971, Doherty 1987), and fisheries have utilized lights to capture commercially valuable species such as squid and herring (Ben-Yami 1976, Pascoe 1990). Phototactic responses in fish can vary by species and life-stage (Dragesund 1958, Ben-Yami 1976, Marchesan et al. 2005).

Continuous artificial illumination of ocean net-pens in coastal British Columbia, Canada, throughout the winter and spring months has become common practice for Atlantic salmon Salmo salar farms in the second sea winter of production (Hay et al. 2004, I. Roberts pers. comm.), yet few studies have considered the effect these artificial lights may have on the distribution and abundance of marine organisms around the farms (Hay et al. 2004). Freshwater zooplankton abundance is higher around aquaculture lights (Mamcarz 1995) and marine zooplankton appear to occur in higher abundance around lit salmon farms; however, these findings were confounded by control and treatment location (Hay et al. 2004). To our knowledge, there has been no investigation into the role lights play in the abundance of marine fish around lit salmon farms. Aggregations of fish ranging from 12 to 2837 times larger than control sites have been reported around Atlantic salmon farms in Scotland (Carss 1990), as well as under guilthead seabream Sparus aurata and European sea bass Dicentrarchus labrax fish farms in the Mediterranean Sea and the Canary Islands (Dempster et al. 2002, 2004, Boyra et al. 2004). There is no indication that lights were used on the farms during 
these studies, and aggregations of fish around active farms were attributed to the presence of excess fish food and to chemical cues from the farmed fish (Dempster et al. 2002). Farm structures were not implicated in the aggregations as, emptied of farmed fish, they attracted 50 times less fish than when in use, and only 1.7 times more fish than control sites (Boyra et al. 2004, Tuya et al. 2006).

Aggregations of marine organisms in and around fish farms may result in (1) predation of wild fish and zooplankton by farmed fish, (2) increased predation on zooplankton by wild fish, and (3) an increased probability of pathogen transmission between wild and farmed fish. Farmed Atlantic salmon consume invertebrates at least occasionally (Hay et al. 2004), although only a single fish has been found in farmed Atlantic salmon stomachs (Hay et al. 2004). However, very little farm fish feed was found in the same stomachs; hence, actual consumption rates may differ from those measured (Hay et al. 2004). Moreover, farmed chinook and coho salmon consume wild fish and invertebrates (Black et al. 1992). In regards to wild fish predation upon zooplankton, chum experienced increased feeding opportunities under security lights (Prinslow et al. 1980), and cottids consumed a higher percentage of sockeye salmon Oncorhynchus nerka fry under lit conditions (Tabor et al. 2004). Finally, increasing the abundance of wild fish directly adjacent to farmed populations increases the potential for pathogen transfer and emergent disease in both wild and farmed populations (Daszak et al. 2000). As such, disease transmission remains a concern, particularly when farmed and wild fish occur sympatrically, as is the case in British Columbia, where farmed salmon occur in the same nearshore environment as numerous wild species including 7 species of pacific salmonids (Groot \& Margolis 1991) and Pacific herring Clupea pallasi.

Given the potential for continuous illumination from ocean net-pen salmon farms to influence the distribution and abundance of marine invertebrates and fish, we quantified the effect of lights on invertebrates and fish abundance in an area of intensive salmon aquaculture in coastal British Columbia. By examining the influence of light in the absence of a salmon farm, we effectively controlled for the confounding influences of excess fish feed, Atlantic salmon, and their feces.

\section{MATERIALS AND METHODS}

Location and study design. A SeeBrite ${ }^{\mathrm{TM}}, 400 \mathrm{~W}$ (36000 lumens), metal halide underwater light such as those used on salmon farms was suspended from a float at the Salmon Coast Field Station on Gilford Island, British Columbia (BC), Canada $\left(50^{\circ} 44^{\prime} 44^{\prime \prime} \mathrm{N}\right.$, $\left.126^{\circ} 29^{\prime} 54^{\prime \prime} \mathrm{W}\right)$. The illumination adjacent to the light bulb was approximately equivalent to full daylight. Illuminance from a light source will depend heavily on turbidity-influenced light attenuation; however, estimates for extreme values of the attenuation coefficient $(k)$ were drawn from measurements of attenuation rates for photosynthetically active radiation from ambient sunlight as measured by R. Routledge (data not shown) in nearby Rivers Inlet, BC, between February 20 and April 29, 2008. Using the formula: $I_{d}=I_{0} \times \mathrm{e}^{-k d} d^{-2}$ (Duntley 1963), where $I_{0}$ is the inherent illuminance of the light (taken to be $400 \mathrm{~W}$ ) and $I_{d}$ is the illuminance level at distance $d$ from the light; illuminance levels may have ranged between 13.002 and $15.258 \mathrm{~W} \mathrm{~m}^{-2}$ at $5 \mathrm{~m}$ from the light, 2.641 and $3.637 \mathrm{~W} \mathrm{~m}^{-2}$ at $10 \mathrm{~m}$, 0.436 and $0.827 \mathrm{~W} \mathrm{~m}^{-2}$ at $20 \mathrm{~m}$, and 0.020 and $0.100 \mathrm{~W}$ $\mathrm{m}^{-2}$ at $50 \mathrm{~m}$ from the light. Plankton hauls were conducted on 42 nights between February 9 and April 10, 2009; purse seines were conducted on 34 nights between February 26 and April 25, 2009. Paired samples were used to control for seasonal changes in abundance of the sample organisms: each illuminated night (a lit night) was paired with a control night when the light was not on. The order of the treatments (lit or control) on paired nights was alternated over successive samples. The light was positioned $1 \mathrm{~m}(2 \mathrm{~m}$ for the first 4 nights of plankton sampling) below the water surface, $1 \mathrm{~m}$ off the float and $\sim 20 \mathrm{~m}$ from the shore, at an ocean depth averaging $12 \mathrm{~m}$ at low tide. The light was turned on $1 \mathrm{~h}$ before sunset as calculated by the National Research Council Canada Sunrise/Sunset/ Sun Angle Calculator (www.nrc-cnrc.gc.ca/eng/services/ hia/sunrise-sunset/angle-calculator.html) and left on until sampling was completed, except for a period of about $15 \mathrm{~min}$ in the middle of the night when the generator was refueled. This short period of darkness occurred at least $3.5 \mathrm{~h}$ before any sampling times. The generator was located about $50 \mathrm{~m}$ away from the study site on land to reduce the impact of noise and vibrations. The period between dusk and dawn ranged from 18:45 to 06:36 h on the night of February 9, decreasing to between 21:02 and 03:45 h by the night of April 25 . The data were often zero skewed for both invertebrates and fish, and distribution-free statistical tests were used to account for this.

Plankton hauls. Vertical plankton hauls were made $2 \mathrm{~h}$ after sunset using a $250 \mu \mathrm{m}$ mesh plankton net, $0.5 \mathrm{~m}$ in diameter and $2.5 \mathrm{~m}$ in length. The net was lowered to a depth of $7 \mathrm{~m}, 3 \mathrm{~m}$ away from the light, pulled to within $1 \mathrm{~m}$ of the light, held for $1 \mathrm{~min}$, then pulled up at $\sim 0.5 \mathrm{~m} \mathrm{~s}^{-1}$. The net was then washed down with seawater, plankton samples were narcotized with 30 to $90 \mathrm{ml}$ of soda water (according to the sample volume) and placed in a fridge overnight before processing. Samples were filtered onto a $118 \mu \mathrm{m}$ mesh screen, 
left to drain for $5 \mathrm{~min}$, and then weighed on a tared scale. Samples were then split 3 to 7 times to obtain 1000 individual zooplankters in the final split. Zooplankters were enumerated under 20 to $40 \times$ magnification and classified into distinctly recognizable taxonomic categories in accordance with Todd et al. (1996). The count number was multiplied by 2 to the power of the number of splits to obtain an estimate of the zooplankters caught in the sample as a whole (Kane 2009). In order to test for an effect of tidal cycle on abundance, an additional plankton haul was made within half an hour of high tide on 14 of the lit nights and 14 of the control nights. The $2 \mathrm{~h}$ samples always occurred earlier than the high tide samples. The Wilcoxon signed rank test (Hollander \& Wolfe 1973) was used to test the null hypothesis that there is no difference in the distributions of the $2 \mathrm{~h}$ and high tide samples when paired over the same night.

Purse seines. Fish were collected using a $5.5 \times 36.6 \mathrm{~m}$ purse seine with a $15.9 \mathrm{~mm}$ mesh, and a $9.1 \mathrm{~m}$ bunt with a $6.25 \mathrm{~mm}$ mesh. Two boom sticks (logs) extending out from the float provided a triangular frame within which the net was arranged in $\sim 12 \times 12 \times 12 \mathrm{~m}$ triangle (Fig. 1) before sunset. While it would have been preferable to collect samples at a constant time after sunset, as was done for the plankton hauls, samples were collected at high tide (between 1 h 42 min and 9 h 24 min after sunset) to avoid complications due to currents. Procedures changed slightly over the season in an effort to capture

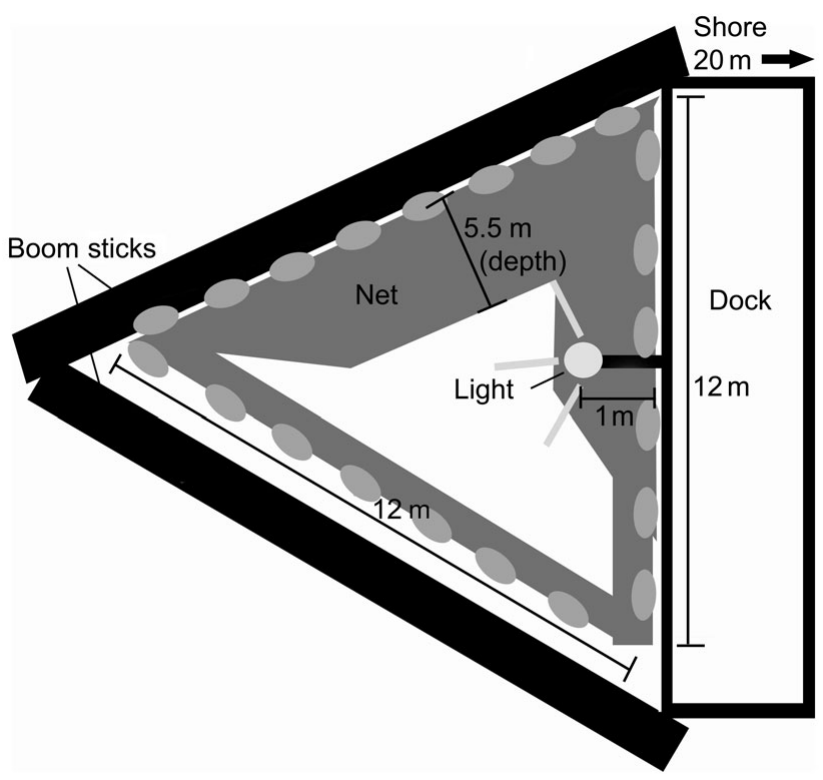

Fig. 1. Bird's eye view of experimental set up. Purse seine (dark grey): $5.5 \mathrm{~m}$ deep $\times 36.6 \mathrm{~m}$ long, arranged in a triangle against the dock and a boom stick frame (black). Half of the net was deployed (top half of the diagram), while the other half was cinched up at the surface of the water. The net hung essentially vertically; the perspective has been exaggerated to emphasize the deployment clearly visible fish that were evading the net. Half of the net was left down and half was cinched-up at the surface of the water to allow free passage of organisms around the light except for the first 6 sample nights, in which all of the net was cinched up at the surface. On each sample night, the cinched-up portion of the net was released and the net was pulled in. For the first 4 samples, the net was released and pulled in rapidly. In subsequent samples, between 5 and 10 min were allowed to elapse in an effort to allow fish startled by the release of the net to return before it was pulled in. For the first 8 lit samples, the light was left on while the net was pulled in. In the remaining 9 lit samples, the light was turned off just before the net was pulled in. All changes to methodology were made to both lit and control paired samples. To check for a confounding influence due to the change in the light protocol (left on or turned off) while the net was pulled in, the Wilcoxon rank sum test (Hollander \& Wolfe 1973) was used to test the null hypothesis that the distribution of the differences in the first 8 paired samples did not differ from the distribution of the differences in the remaining 9 paired samples. All fish captured were transferred to buckets, identified to species, enumerated, and released. Fish larvae were examined under a microscope and identified by vertebral counts according to the Ichthyoplankton information system (http://access.afsc. noaa.gov/ichthyo/index.cfm).

Analysis. To assess the possibility that the order of treatment may influence the differences in abundance between paired nights, the Wilcoxon rank sum test was used to test the null hypothesis that the distributions of samples when lit nights occurred first has the same mean as the distribution of samples when the control came first. When no influence of the order of treatments was found, the data were pooled and the Wilcoxon signed rank test was used to test the null hypothesis that there was no change in abundance between lit and control treatments. As multiple statistical tests were performed on the same data, the tests were repeated with separate Bonferroni correction factors applied to the plankton haul taxa and the species gathered in the purse seines (Devore 2004). However, because the present study may suffer from confounding factors such as tide and moon cycles (see 'Discussion'), and is a novel application to aquaculture, undue emphasis was not placed on the results of these tests so that less obvious patterns in the data would not be overlooked. For the total invertebrate, total juvenile and adult fish and total fish larvae count only, a rankbased estimate of the ratio of abundance on lit versus control nights and associated rank-based confidence intervals were calculated (Hollander \& Wolfe 1973). All computations were performed with the statistical package $\mathrm{R}$ v2.8.1 at an $\alpha$ level of 0.05. 


\section{RESULTS}

\section{Plankton hauls}

On lit nights, an estimated 680798 invertebrates were caught in the $2 \mathrm{~h}$ tows, compared to an estimated 456024 invertebrates on control nights. On lit nights, there was no difference in total invertebrate abundance between the earlier $2 \mathrm{~h}$ and the later high tide samples ( $p=0.0906)$, although significantly more scyphozoans $(p=0.0369)$ were observed in the $2 \mathrm{~h}$ samples and significantly more amphipods $(p=0.0360)$ were observed in the high tide samples (Wilcoxon signed rank tests). Likewise, on control nights, total invertebrate abundance did not differ between $2 \mathrm{~h}$ and high tide samples ( $p=0.2958)$, although significantly more gastropods $(p=0.0056)$, bivalves $(p=0.0056)$, and calanoid copepods ( $p=0.0017$ ) were observed in high tide samples. The $2 \mathrm{~h}$ samples were used for the following analysis. The total invertebrate rank-based estimate of the ratio of abundance increased by a relatively modest but significant $(p=0.0460)$ factor of 1.38 on lit versus control nights (Wilcoxon signed rank test), with $95 \%$ confidence limits of 1.07 to 1.81 . Although only gastropods and bivalves showed a significant change in abundance, of the 43 taxa/life-stages found, 9 occurred exclusively on lit nights while only 1 (Holothuroidea) occurred exclusively on control nights; 23 other taxa were more abundant on lit nights (Fig. 2, Table 1). Because many taxa occurred at low frequencies, unidentified taxa and taxa observed at $<0.5$ ind. night ${ }^{-1}$ (a natural break-point between higher and lower abundances in the data) are not reported in Fig. 2, but are listed in Table 1. No taxa showed a significant difference when a Bonferroni correction factor was applied.

\section{Purse seines}

Tests on the 2 different protocols (light left on or light turned off) used when pulling in the seine net on a lit night found a significant difference in chum salmon ( $\mathrm{p}=$ $0.0441)$, unidentified fish larvae $(p=0.0162)$ and total fish larvae ( $p=0.0168$; Wilcoxon rank sum test). All 3 groups showed a greater increase on lit nights during which the light was turned off before the purse seine was pulled in. These samples occurred in the second half of the season when chum salmon and fish larvae would be expected to occur in greater abundance. As no other species showed any difference over the 2 protocols, the data were pooled across protocol types in subsequent analyses. More juvenile and adult fish were caught on lit (643) than on control nights (122), and the rank-based estimate of the ratio of lit versus control abundance was 9.5 ( $\mathrm{p}=$ 0.0014; Wilcoxon signed rank test; Fig. 3), with $95 \%$
Table 1. Plankton haul invertebrates. Two-sided Wilcoxon signed rank tests results (without correction factor) testing for change in abundance between lit and control nights for organisms not reported in Fig. 2 (unknown organisms and organisms present at $<0.5$ ind. night ${ }^{-1}$ ), total for all invertebrates observed, and wet weight of each sample. Significance: ${ }^{*} \mathrm{p}<0.05$

\begin{tabular}{|lc|}
\hline Taxa/life stage & p-value \\
\hline Caligus adult & 1.000 \\
Caridea zoea & 1.000 \\
Copepoda, unidentified & 1.000 \\
Crustacea, unidentified & 0.174 \\
Euphausiacea adult & 1.000 \\
Mysidacea & 1.000 \\
Polychaeta, unidentified & 0.181 \\
Unidentified 1 & 1.000 \\
Unidentified 2 & 1.000 \\
Unidentified 3 & 0.572 \\
Unidentified 4 & 1.000 \\
Unidentified 5 & 1.000 \\
Total & $0.046^{*}$ \\
Weight & 0.380 \\
\hline
\end{tabular}

confidence limits of 3.90 to 25.63. More fish larvae were caught on lit nights (154) than control nights (5), a rankbased estimated increase of a factor of $8.72(p=0.0025$; Fig. 3) with confidence limits of 4.58 to 26.55. In contrast, macro-invertebrates caught in the purse seine were more numerous on control nights although not significantly so (825 ind. on control versus 638 on lit nights, $\mathrm{p}=0.6700$; Fig. 3). Fish species present at an average of $<0.3$ ind. night ${ }^{-1}$ (a natural break point in the data) were placed together in an 'other' category (Table 2). No species showed a significant difference when a Bonferroni correction factor was applied.

\section{DISCUSSION}

\section{Invertebrates}

These results demonstrate a marginally significant increase in marine invertebrates around the light on lit nights compared to control nights, although the abundance close to the light is likely less than double the control abundance. The increased abundance of gastropods, bivalves, and calanoid copepods at high tide on control nights but not lit nights may indicate that their behaviour is influenced in some manner by both the light and the tidal cycle. Invertebrates may also respond to environmental cues such as lunar cycle, wind, and cloud conditions (Queiroga \& Blanton 2004). Ambient light levels varied during the study depending on cloud cover and moon phase. As paired samples occurred over 2 sequential nights, these results are somewhat obscured by the differences in these environmental variables, as well as the patchy distribution and 


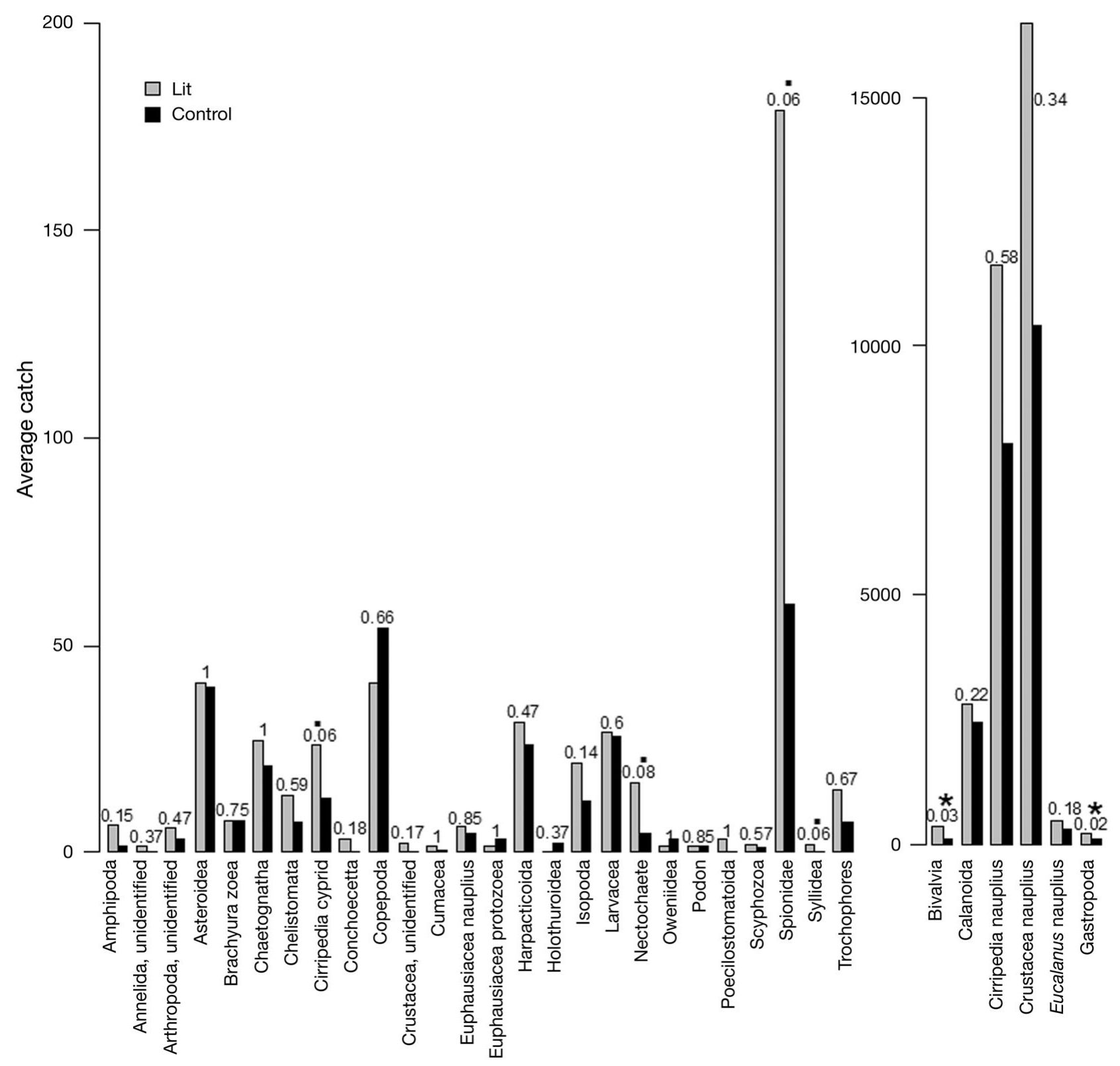

Fig. 2. Plankton haul average catch on lit and control nights. High abundance organisms plotted on separate axis on the right. Taxa observed at an average of $<0.5$ ind. night ${ }^{-1}$ and unknown taxa are excluded (see Table 1). Members of Syllidea were observed only on lit nights. Two-sided Wilcoxon signed rank test results are marked. Significance: $\boldsymbol{\sim} p<0.10,{ }^{\star} \mathrm{p}<0.05$

changing abundances of organisms (Omori \& Hamner 1982) from night to night. Additionally, the intensity of the artificial light may also play a role as light-assisted zooplankton catches are highest when lower light intensities (27 lux or $2.5 \mathrm{~V}$ ) are used (Sheard 1941, Hale 1953) and several laboratory studies have found organisms to be attracted to low but not high light intensities (Crisp \& Ritz 1973, reviewed in Forward 1988). Many invertebrates may therefore be repelled from the full brightness of the $400 \mathrm{~W}$ light and/or gather at some distance from the light at a more preferable light level.

\section{Invertebrate aggregations around lit farms}

Plankton tows 60 to $80 \mathrm{~m}$ away from a lit and an unlit farm in northern Johnstone Strait during the day in June and July (Hay et al. 2004) found 19 taxa also found in the present study, with an additional 14 taxa only observed in the present study and 4 taxa only found by Hay et al. (2004). Some organisms such as the crustacean nauplii and poecilostomatoids observed in the present study may have been too small to be captured by the larger net mesh size used by Hay et al. 


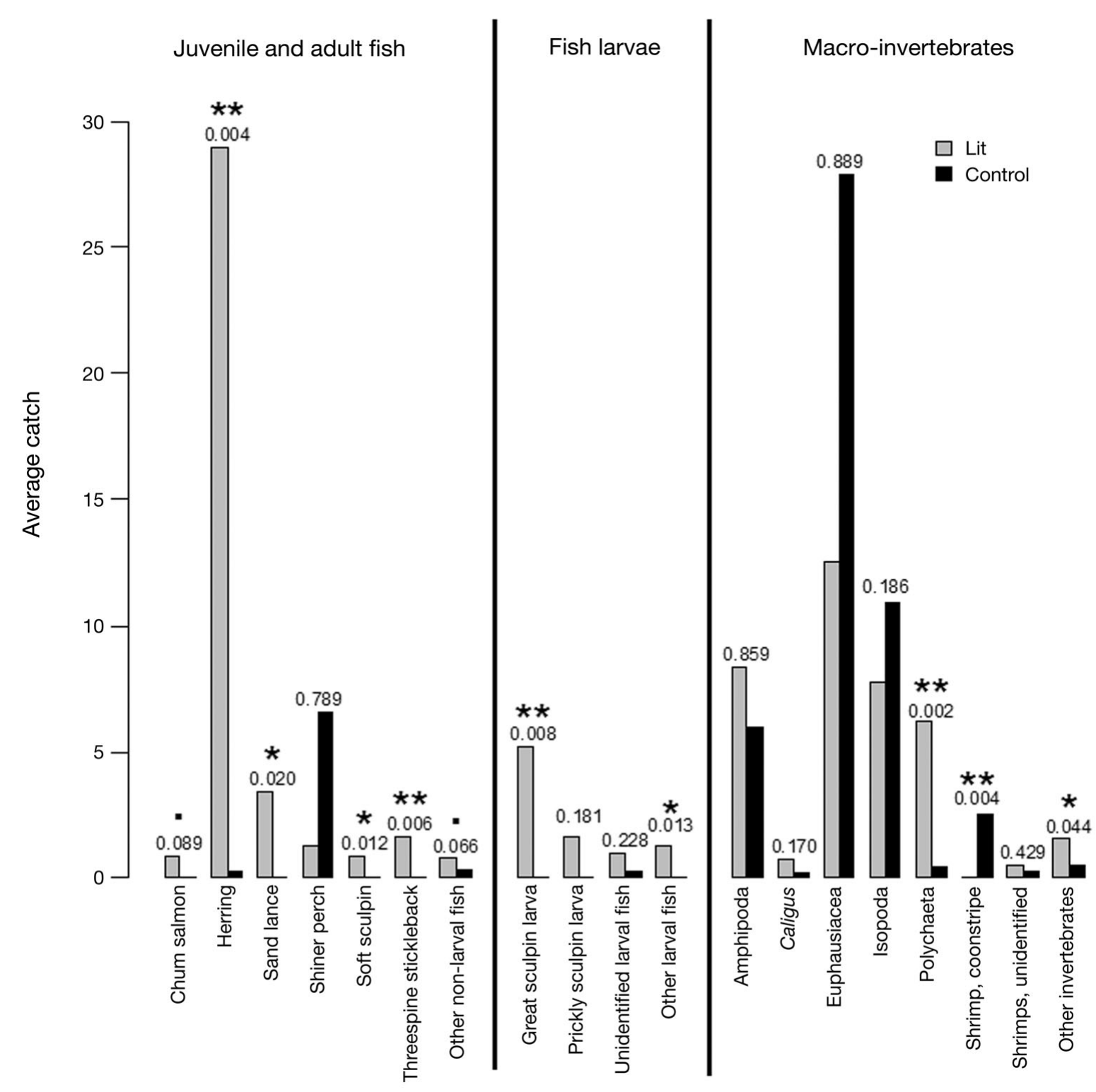

Fig. 3. Purse seine average catch on lit and control nights for juvenile and adult fish, fish larvae, and macro-invertebrates. Fish and invertebrates catch at an average of $<0.3$ ind. night ${ }^{-1}$ are included in 'other' categories (see Table 2). Chum salmon, sandlance, threespine stickleback, snail fish larvae, great sculpin larvae, and prickly scuplin larvae were observed only on lit nights.

Two-sided Wilcoxon signed rank test results are marked. Significance: $\mathrm{p}<0.10,{ }^{*} \mathrm{p}<0.05, * \star \mathrm{p}<0.01$

(2004). Others such as scyphozoans, asteroid larvae and holothuroid larvae (observed in the present study), and crab megalops (observed by Hay et al. 2004) are only present in the plankton at a specific time of year, and may simply have been absent during one or other of the studies (Ruppert et al. 2004). Cumaceans and isopods are primarily benthic (Ruppert et al. 2004) and may be excluded by much larger sampling distance from structures and presumably deeper depths at the sample location used by Hay et al. (2004). Ocean depth at sampling point was not reported by Hay et al. (2004), but the plankton haul was conducted from $20 \mathrm{~m}$ depths, while the bottom depth at the sample site for the present study was $\sim 12 \mathrm{~m}$ at low tide.) Different sampling times (day versus night) may also contribute to the different taxa found.

Our study found a 1.15 times non-significant increase in copepod abundance (and a significant increase of 1.49 times higher total zooplankton) in contrast to a maximum of 19.3 times higher copepod densities in illuminated freshwater cages holding coregonid fish compared to a location $3 \mathrm{~m}$ away (Mamcarz 1995). Mamcarz (1995) conducted lit and control tows on the same night and the disparity in our results may 
Table 2. Purse seine catches for taxa from 'other' categories in Fig. 3. Results of 2-sided Wilcoxon signed rank tests (without correction factor) testing for a change in abundance between lit and control nights, and count data displayed. $\mathbf{p}<<0.10$

\begin{tabular}{|c|c|c|c|c|}
\hline \multirow{2}{*}{ Species common name } & \multirow{2}{*}{ Taxon } & \multirow{2}{*}{ p-value } & \multicolumn{2}{|c|}{ - Counts } \\
\hline & & & Lit & Control \\
\hline \multicolumn{5}{|l|}{ Other juvenile and adult fish } \\
\hline Banded Irish lord juvenile & Hemilepidotus.gilberti & 1.000 & 1 & 0 \\
\hline Buffalo sculpin & Enophrys bison & 1.000 & 1 & 0 \\
\hline Gunnel & Pholidae sp. & 1.000 & 1 & 0 \\
\hline Kelp greenling & Hexagrammos decagrammus & 0.072 - & 4 & 0 \\
\hline Norther spearnose poacher & Agonopsis vulsa & 1.000 & 1 & 0 \\
\hline Pacific staghorn sculpin & Leptocottus armatus & 1.000 & 0 & 1 \\
\hline Quill fish & Ptilichthys goodie & 1.000 & 1 & 0 \\
\hline Rock fish & Scorpaenidae sp. & 1.000 & 1 & 0 \\
\hline Snail fish & Unnamed, Liparidae sp. & 1.000 & 1 & 1 \\
\hline Surf perch & Embiotocidae sp. & 1.000 & 0 & 1 \\
\hline Tubesnout & Aulorhynchus flavidus & 1.000 & 1 & 1 \\
\hline Walleye pollock & Theragra chalcogramm & 1.000 & 2 & 1 \\
\hline \multicolumn{5}{|l|}{ Other fish larvae } \\
\hline Dwarf wrymouth & Cyptacanthodes aleutenis & 0.098 " & 8 & 0 \\
\hline Giant kelpfish & Heterostichus rostratus & 1.000 & 0 & 1 \\
\hline Giant wrymouth & Cryptacanthodes giganteus & 1.000 & 2 & 0 \\
\hline Pricklebreast & Stellerina xyosterna & 0.371 & 3 & 0 \\
\hline Sandlance & Ammodytes hexapterus & 1.000 & 1 & 0 \\
\hline Silver spotted sculpin & Blepsia cirrhosus & 1.000 & 1 & 0 \\
\hline Snail fish & Liparidae sp. & 1.000 & 5 & 0 \\
\hline Snake prickleback & Lumpenus sagilla & 1.000 & 1 & 0 \\
\hline White-spotted greenling & Hexagrammos stelleri & 1.000 & 1 & 0 \\
\hline \multicolumn{5}{|l|}{ Other macro-invertebrates } \\
\hline Brachyura & & 0.773 & 2 & 1 \\
\hline Mysidacea & & 0.149 & 0 & 3 \\
\hline Shrimp, crangon & Crangon spp. & 0.407 & 6 & 3 \\
\hline Shrimp, spiny pink & Pandalus eous & 0.054 • & 13 & 0 \\
\hline Stubby squid & Rossia pacifica & 0.089 • & 6 & 0 \\
\hline Winged sea slug & Gasteropteron pacificum & 0.371 & 4 & 1 \\
\hline
\end{tabular}

indicate that the increased abundance of zooplankton around the light in Mamcarz's study was concurrent with a decrease in zooplankton abundance nearby. Alternatively the increased abundance may be related to the dimmer $60 \mathrm{~W}$ underwater light used by Mamcarz (1995) (as discussed above), or disparate responses in freshwater species.

\section{Light-mediated invertebrate behaviour}

Many benthic organisms have a planktonic larval stage that is important in species dispersal (Cowen \& Sponaugle 2009). Larval stages are initially photopositive, enabling them to avoid benthic predators. Before settlement, the later larval stages, particularly in sublittoral species that must settle below the low tide line, become negatively phototactic (Thorson 1964 in Crisp $\&$ Ritz 1973). Stages in-between vary in their response to light, but commonly undergo diel vertical migrations (Thorson 1964 in Crisp \& Ritz 1973). Crustacean nauplii (the first larval stage) and cirripedia nauplii in particular were more common on lit nights in the present study, while holothuroid pentactula larvae are nearing settlement and were found only on control nights. Conversely, while the settling stage of barnacles (cyprids) have a reported negative response to light and have been induced to settle by increases in light intensity (Crisp \& Ritz 1973), barnacle cyprids in the present study were more common on lit nights.

\section{Implications for invertebrates}

Although little indication of a large increase in invertebrate abundance was found in the present study, artificial lights have the potential to disrupt normal light-dependent patterns such as breeding swarms in polychaetes (reviewed in Franke 1999) and may attract other invertebrates through a variety of mechanisms, many of which are not precisely known. Even in the absence of a large increase in marine invertebrates, artificial lights make invertebrates more visible and easier prey to predators (Batty et al. 1990, Blaxter \& Batty 1990, Nightingale et al. 2006). This may in turn (1) attract predators such as small fish and (2) increase the likelihood that farmed Atlantic salmon will feed upon wild invertebrates. Atlantic salmon escapees may 
thereby be preconditioned to eat wild prey and better able to survive outside of the net-pens (Morton \& Volpe 2002). Finally, sea lice are of particular concern to the salmon farming industry, and the nauplii and copepodids of Lepeophtheirus salmonis are attracted to artificial light (Pahl et al. 1999). This may cause sea lice to remain in the farm net-pens longer than predicted by ocean current models (Brooks 2005, Murray \& Gillibrand 2006) and increases the potential for re-infection of farmed fish (Hevroy et al. 2003). Light-mediated interactions between sea lice and farmed or wild fish would benefit from further research.

\section{Fish}

\section{Pacific herring}

The photopositive behaviour of the Pacific herring Clupea pallasi observed in the present study has likewise been reported in juvenile Atlantic herring C. harengus and Pacific herring (see reviews by Ben-Yami 1976 and Blaxter \& Batty 1990). Other observations of Atlantic herring, however, find the primary reaction is to school more densely and descend away from an increase in artificial light intensity (Dragesund 1958). The mechanism for diel vertical migration in which Atlantic herring follow preferred isolumes of 1 to 10 lux to the surface at dusk and back to the depths at dawn (the Preferendum hypothesis) (Blaxter 1974) is not likely the same mechanism by which these juvenile Pacific herring were attracted to artificial light. Although the illumination at the maximum distance from the light encircled by the net $(\sim 11 \mathrm{~m})$ would only be $\sim 15$ lux maximum - nearly within the reported range-Pacific herring in the present study were observed in the full brightness of the light (a maximum of 36000 lux). Alternatively, photopositive behaviour may be related to feeding or schooling behaviour. The Pacific herring were observed actively feeding and schooling under the light, and may be enticed to feed where the prey are more visible (Batty et al. 1990, Blaxter \& Batty 1990). Schooling is beneficial as an antipredator response but can only occur at light levels above 0.5 to 10 lux (reviewed in Blaxter \& Batty 1990, Nightingale et al. 2006).

\section{Chum salmon}

The spring out-migration of pink (Oncorhynchus gorbuscha) and chum (O. keta) salmon throughout the study site does not normally occur until April; as such, they were likely only present in the area for the last few samples. The absence of pink salmon in the present study may simply indicate that none had yet migrated into the area so early in the season, particularly because pink and chum salmon are usually found together (Groot \& Margolis 1991) and have similar reported reactions to light (Hoar et al. 1957). Chum salmon were caught only on lit nights, but the results are not statistically significant due to the small number of catches containing them. Both chum and pink salmon are attracted to light at low intensities (54 to 5382 lux), but only chum salmon retreat from light at high intensities (10 764 lux) (Hoar et al. 1957). Similarly, the chum salmon in the present study were observed schooling in the dimmer zone at the surface above the light. Pink and chum salmon fry are most attracted to light levels to which they are previously adapted (reviewed in Feist \& Anderson 1991, Simenstad et al. 1999). It follows that low catches of chum salmon would occur, for chum salmon straying into the lit zone after dusk would be repelled by the contrast between the dark (to which they would be currently adapted) and the bright artificial light. It would be valuable to conduct a similar study during the migrations of juvenile pink and chum salmon. The trends observed in the present study suggest that further investigation may reveal a significant attraction to farm lights, and such behaviour may be relevant to sea louse transmission dynamics (Krkošek et al. 2007).

\section{Other fish}

Threespine stickleback Gasterosteus aculeatus, Pacific sand lance Ammodytes hexapterus, soft sculpin Psychrolutes sigalutes and larval great sculpin Myoxocephalus polyacanthocephalus were also significantly more abundant on lit nights, while shiner perch $C_{Y}$ matogaster aggregata were the only fish caught more frequently on control nights. To our knowledge, no research exists on the phototactic tendencies of these species, although sculpins of another species feed more successfully on migrating sockeye salmon under lit conditions (Tabor et al. 2004). In the present study, catches of smaller fish such as threespine stickleback, Pacific sand lance and juvenile chum salmon may be artificially low since the fish could escape through the large mesh of the main part of the net, even though the mesh of the bunt was fine enough to successfully contain them. Sand lance were in fact observed swimming easily out of the main mesh of the net.

\section{Fish aggregations around lit farms}

In examining the ecological impact of farm lights, Hay et al. (2004) did not specifically examine the wild fish around lit and unlit farms; however, more fish larvae were caught in daytime plankton tows at lit farms 
compared to unlit farms (11 versus 3 fish larvae). Several studies have examined wild fish abundances around fish farms in northern Georgia Strait without reference to lights. Pacific herring, threespine stickleback, and schools of 10000 s of pink and chum salmon fry have been observed in the net-pens of salmon, while nearby purse seines commonly caught young Pacific herring and pink salmon (Black et al. 1992).

\section{Implications for fish}

Over 100 times more Pacific herring were seen on lit nights compared to dark nights, but visual estimates of Pacific herring that evaded the net and were schooling around the light on lit nights range from 10s to 1000 s. If large aggregations of a commercially important fish species occur near farmed species, it may be cause for concern. There would be a risk of predation by Atlantic salmon on wild fish, and Pacific herring have been identified in the stomachs of farmed chinook salmon Oncorhynchus tshawytscha (Black et al. 1992). A more considerable concern when wild stocks and farmed stocks intermingle is the transfer of pathogens (Daszak et al. 2000).

Pathogens are one of the principal threats to aquaculture (Mohan et al. 2008), and likewise can endanger sympatric wild fish populations (Daszak et al. 2000). Infectious hematopoietic necrosis (IHN) epidemics in farmed salmon in BC, which recently resulted in over 12 million deaths of farmed Atlantic salmon (Saksida 2006), may have affected or been spread by migratory wild fish. Sea lice from salmon farms are associated with depressed and declining wild pink and chum salmon populations in areas of intensive salmon aquaculture in BC. (Krkošek et al. 2007). In light of these pathogen-mediated interactions between wild and farmed salmon and the rate at which pathogens can spread in marine environments (McCallum et al. 2003), the use of continuous illumination at salmon farms, if it results in higher abundances of wild fish near the farms, may increase the probability, severity or rate at which pathogen transmission occurs.

These findings agree with others that suggest continuous lighting in marine areas as well as terrestrial systems (Rich \& Longcore 2006 and references therein) constitutes an attractive influence over various organisms. Care must be taken when extrapolating these results to salmon farms. The present study used only one non-farm sample site and thus cannot control for different environmental factors at different locations, nor can it predict wild fish and invertebrate behaviour around artificial lights in conjunction with farms themselves. The present study does raise the possibility that the use of lights may lead to the aggregation of invertebrates and pelagic fishes around aquaculture pens, potentially increasing interactions between farmed fish and wild organisms. Given their ecological and economic importance, further studies on Pacific herring and chum and pink salmon aggregations around Atlantic salmon farms are warranted. A logical next step would be to determine the distance from which fish farm lights can attract species, and to investigate what proportion of economically or ecologically important wild populations they may influence. Finally, any impacts of fish farm lights may not be isolated to fish and invertebrates, as harbor seals Phoca vitulina and sea birds are also attracted to artificial light (Yurk \& Trites 2000, Wiese et al. 2001, Poot et al. 2008). During the present study, several seals and an otter were observed around the light; it would be beneficial to investigate the impact of the lights on local marine mammals and sea birds.

Acknowledgements. Thanks to L. Dill for comments on the manuscript and assistance with study design, J. Reynold for comments on the manuscript, S. Rogers and A. Park for assistance while sampling, A. Morton for continued advice, equipment and lodgings, M. Galbraith for assistance identifying zooplankton, D. Stable for assistance identifying fish, and M. Krkošek for statistics advice. Thanks also to M. Adams, C. Lagasse, L. Honka, A. Bateman and A.Yeomans-Routledge for work in the field. Partial support for this project was provided by an NSERC discovery grant to R.R. This study was conducted in accordance with animal care guidelines.

\section{LITERATURE CITED}

Batty RS, Blaxter JHS, Richard JM (1990) Light intensity and the feeding behaviour of herring, Clupea harengus. Mar Biol 107:383-388

Ben-Yami (1976) Fishing with light. In: Food and Agriculture Organization of the United Nations (FAO). Fishing News Books, Farnham, p 6-49

Black EA, Gillis DJ, Hay DE, Haegele CW, Levings CD (1992) Predation by caged salmon in British Columbia. Bull Aquacult Assoc Can 92:58-60

Blaxter JHS (1974) The role of light in the vertical migration of fish-a review. In: Evans GC, Bainbridge R, Rackham O (eds) Light as an ecological factor: II. Blackwell Scientific Publications, Oxford, p 189-210

Blaxter JHS, Batty RS (1990) Herring behaviour in the light and dark. In: Herring PJ, Campbell AK, Whitfield M, Maddock L (eds) Light and life in the sea. Cambridge University Press, Plymouth, p 209-220

Boyra A, Sanchez-Jerez P, Tuya F, Espino F, Haroun R (2004) Attraction of wild coastal fishes to an Atlantic subtropical cage fish farms, Gran Canaria, Canary Islands. Environ Biol Fishes 70:393-401

Brooks KM (2005) The effects of water temperature, salinity, and currents on the survival and distribution of the infective copepodid stage of sea lice (Lepeophtheirus salmonis) originating on Atlantic salmon farms in the Broughton Archipelago of British Columbia, Canada. Rev Fish Sci 13: 177-204

Carss DN (1990) Concentrations of wild and escaped fishes immediately adjacent to fish farm cages. Aquaculture 90: $29-40$ 
Cowen RK, Sponaugle S (2009) Larval dispersal and marine population connectivity. Annu Rev Mar Sci 1:443-466

Crisp DJ, Ritz DA (1973) Responses of cirripede larvae to light. I. Experiments with white light. Mar Biol 23:327-335

Daszak P, Cunningham AA, Hyatt AD (2000) Emerging infectious diseases of wildlife: threats to biodiversity and human health. Science 287:443-449

> Dempster T, Sanchez-Jerez P, Bayle-Sempere JT, GiménezCasalduero F, Valle C (2002) Attraction of wild fish to seaage fish farms in the south-western Mediterranean Sea: spatial and short-term temporal variability. Mar Ecol Prog Ser 242:237-252

> Dempster T, Sanchez-Jerez P, Bayle-Sempere J, Kingsford M (2004) Extensive aggregations of wild fish at coastal seacage fish farms. Hydrobiologia 525:245-248

Devore JL (2004) Probability and statistics for engineering and the sciences. Brooks/Cole-Thomson Learning, Toronto

Doherty PJ (1987) Light-traps: selective but useful devices for quantifying the distributions and abundances of larval fishes. Bull Mar Sci 41:423-431

> Dragesund O (1958) Reactions of fish to artificial light, with special reference to large herring and spring herring in Norway. ICES J Mar Sci 23:213-227

Duntley SQ (1963) Light in the sea. J Opt Soc Am 53:214-233

Feist BE, Anderson JJ (1991) Review of fish behaviour relevant to fish guidance systems. Fisheries Research Institute, Seattle, WA

Forward RB (1988) Diel vertical migration: zooplankton photobiology and behaviour. Oceanogr Mar Biol Annu Rev 26:361-393

Franke H (1999) Reproduction of the Syllidae (Annelida: Polychaeta). Hydrobiologia 402:39-55

Groot C, Margolis L (1991) Pacific salmon life histories. UBC Press, Vancouver

Hale HM (1953) Notes on distribution and night collecting with artificial light. Trans R Soc S Aust 76:70-76

Hay DE, Bravender BA, Gillis DJ, Black EA (2004) An investigation into the consumption of wild food organisms, and the possible effects of lights on predation, by caged Atlantic salmon in British Columbia. Can Manuscr Rep Fish Aquat Sci 2662. Fisheries and Oceans Canada, Ottawa

Hevroy EM, Boxaspen K, Oppedal F, Taranger GL, Holm JC (2003) The effect of artificial light treatment and depth on the infestation of the sealouse Lepeophtheirus salmonis on Atlantic salmon (Salmo salar L.) culture. Aquaculture 220: $1-14$

Hoar WS, Keenleyside MHA, Goodall RG (1957) Reactions of juvenile Pacific salmon to light. J Fish Res Board Can 14:815-830

Hollander M, Wolfe DA (1973) Nonparametric statistical methods. John Wiley \& Sons, New York, NY

Jones DA (1971) A new light trap for plankton. In: Crisp DJ (ed) Fourth European marine biology symposium. University Press, Cambridge, p 487-493

Kane J (2009) A comparison of two zooplankton time series data collected in the Gulf of Maine. J Plankton Res 31: 249-259

> Krkošek M, Ford JS, Morton A, Lele S, Myers RA, Lewis MA (2007) Declining wild salmon populations in relation to parasites from farm salmon. Science 318:1772-1775

> Longcore T, Rich C (2004) Ecological light pollution. Front Ecol Environ 2:191-198

> Mamcarz A (1995) Changes in zooplankton structure around illuminated cage culture. Aquacult Res 26:515-525

> Marchesan M, Spoto M, Verginella L, Ferrero EA (2005) Behavioural effects of artificial light on fish species of commercial interest. Fish Res 73:171-185

McCallum H, Harvell D, Dobson A (2003) Rates of spread of marine pathogens. Ecol Lett 6:1062-1067
Mohan CV, Philips MJ, Bhat BV, Umesh NR, Padiyar PA (2008) Farm-level plans and husbandry measures for aquatic animal disease emergencies. Rev Sci Tech Off Int Epiz 27:161-173

Morton A, Volpe J (2002) A description of escaped farmed Atlantic salmon Salmo salar captures and their characteristics in one Pacific salmon fishery area in British Columbia, Canada in 2002. Alsk Fish Res Bull 9:102-110

> Murray AG, Gillibrand PA (2006) Modelling salmon lice dispersal in Loch Torridon, Scotland. Mar Pollut Bull 53: 128-135

Nightingale B, Longcore T, Simenstad CA (2006) Artificial night lighting and fishes. In: Rich C, Longcore T (eds) Ecological consequences of artificial lighting. Island Press, Washington, DC, p 257-276

Omori M, Hamner WM (1982) Patchy distribution of zooplankton: behaviour, population assessment and sampling problems. Mar Biol 72:193-200

Pahl BC, Cole DG, Bayer RC (1999) Sea lice control II. J Appl Aquacult 9:75-88

Pascoe PL (1990) Light and the capture of marine animals. In: Herring PJ, Campbell AK, Whitfield M, Maddock L (eds) Light and life in the sea. Cambridge University Press, Cambridge, p 229-244

Poot H, Ens BJ, de Vries H, Donners MAH, Wernand MR, Marquenie JM (2008) Green light for nocturnally migrating birds. Ecol Society 13(2):47

Prinslow TE, Whitmus CJ, Dawson JJ, Bax NJ, Snyder BP, Salo EO (1980) Effects of wharf lighting on outmigrating salmon. Final Report FRI-UW-8007, Fisheries Research Institute, Seattle, WA

Queiroga H, Blanton J (2004) Interactions between behaviour and physical forcing in the control of horizontal transport of decapod crustacean larvae. Adv Mar Biol 47:107-214

Rich C, Longcore T (2006) Ecological consequences of artificial lighting. Island Press, Washington, DC

Ruppert EE, Fox RS, Barnes RD (2004) Invertebrate zoology: a functional evolutionary approach, 7th edn. Brooks/ColeThomson Learning, Toronto

Saksida SM (2006) Infectious haematopoietic necrosis epidemic (2001 to 2003) in farmed Atlantic salmon Salmo salar in British Columbia. Dis Aquat Org 72:213-223

Sheard K (1941) Improved methods for collecting marine organisms. Rec S Aust Mus 7:11-14 (available at www. samuseum.sa.gov.au/Journals/RSAM/RSAM_v007/rsam_ v007_p011p014.pdf)

Simenstad CA, Nightingale BJ, Thom RM Shreffer DK (1999) Impacts of ferry terminals on juvenile salmon migrating along Puget Sound shorelines. Phase I: synthesis of state of knowledge. Final Res Rep, Res Proj T9903, Task A2, Washington Sate Transportation Center (TRAC), Seattle, WA

Tabor RA, Brown GS, Luiting VT (2004) The effect of light intensity on sockeye salmon fry migratory behaviour and predation by cottids in the Cedar River, Washington. N Am J Fish Manag 24:128-145

Todd CD, Laverack MS, Boxshall GA (1996) Coastal marine zooplankton, 2nd edn. Cambridge University Press, Cambridge

Tuya F, Sanchez-Jerez P, Dempster T, Boyra A, Haroun RJ (2006) Changes in demersal wild fish aggregations beneath a sea-cage fish farm after the cessation of farming. J Fish Biol 69:682-697

- Wiese FK, Montevecchi WA, Davoren GK, Huettmann F, Diamond AW, Linke J (2001) Seabirds at risk around offshore oil platforms in the North-west Atlantic. Mar Pollut Bull 42:1285-1290

> Yurk H, Trites AW (2000) Experimental attempts to reduce predation by harbor seals on out-migrating juvenile salmonids. Trans Am Fish Soc 129:1360-1366 